\title{
VIRTUAL ORGANIZATION: SPECIFICS OF CREATION OF PERSONNEL MANAGEMENT SYSTEM
}

\author{
Juozas Merkevičius, Vida Davidavičienè, \\ Jurgita Raudeliūnienè, Jan Buleca
}

\section{Introduction}

Development of Information and communication technologies (ICT) creates new possibilities for organizations management, and human resources management is one of the fields which is strongly effected by ICT. Technological development help to solve specific problems related to personnel management especially in the virtual organizations, which development are caused by ICT as well. Application of ICT in business creates not just opportunities and advantages but cause new challenges for business organizations. Exchange of information via e-mail, web conferences become the common in business activity. A lot of people joining virtual groups, organizations and networks for business development reasons, and using these opportunities intensively. If models applied in human resource management (further in article personnel management) do not meet current market requirements as a consequence can be named decrease of competitiveness, and loss of potential markets. This leads to certain social problems, such as migration, unemployment, social exclusions, etc. This highlight importance of personnel management improvement questions not just aiming for business development but also in terms of solving social aspects in regions and in the state. These circumstances frame the topicality of this article subject.

Goal of the research - to construct model of personnel management of virtual organization, which created possibilities to manage geographically dispersed personnel using information technologies.

Methods of the research - there was applied systematic analysis that allowed disclosing personnel management specifics under the conditions of virtual organizations' development. Performing the research there were used methods of survey, comparison, summarization and documentary analysis.

\section{Previous Research and Theoretical Framework}

Topics of increasing effectiveness of personnel management of traditional organizations were analysed by [33], [6], [27], [30], [7], [13], [26], [14], [21], and [2]. Biggs and Swailes [4] analysed personnel management issues in the perspective of organizational commitment. Melnikas et al. [22] analysed personnel management problems under the conditions of economical systems' transformation, globalization and integration process [37].

Problems of virtual organizations were analysed by [3], [11], [12], [17], [47], [8], [18], [35], [28], [40], [31], [1], [43] and others. Lee [16] analysed the problems of adoption of existing leadership theories to e-leadership also the ability to use progressive tools and techniques leading to improvement of virtual project communications. The empirical evidence suggests that psychic distance can be positively related to performance when it leads to great expectations of challenges, which in turn leads to greater effort [20].

Minas et al. [23] analysed the role of information in the virtual teams and found that information that challenges an individual's pre discussion decision preference is processed similarly to irrelevant information, while information that supports an individual's pre discussion decision preference is processed more thoroughly. Empirical research of Brahm and Kunze [5] suggests that managers should emphasize the development of team trust at early stages of collaboration in a virtual team to reach high performance outcomes. Wilson et al. [44] notes the limitations of the preoccupation with objective measures of diversity in virtual groups' performance and propose the incorporation of perceptual measures to better capture the perceived differences between team members and the resulting reactions, 
behaviours, and team outcomes. Pangil and Chan [29] identifies that team effectiveness are positively associated with trust and knowledge sharing. Their finding emphasizes that organizations need to continue working on organizational support structures that increase trust, which will then help to promote knowledge sharing and finally boosts the virtual team effectiveness.

Empirical research of Lin et al. [19] indicate that communication has no significant direct impact on the effectiveness of virtual teams. Virtual teams focused more on social dimensional factors than the task-oriented factor, social dimensional factors could only affect the satisfaction of virtual teams indirectly through their performance, and there is no significant relationship between the task dimensional factor and the effectiveness of virtual teams. Sarker et al. [36] in their empirical research identify and test three models - additive, interaction, and mediation, describing the role of trust in its relationship with communication to explain performance. In testing the relationships, authors noted that the concepts of communication and trust are inherently relational and not properties of individuals. The results indicate that the mediating model best explains how communication and trust work together to influence performance. Xiao and Jin [45] found that virtual team effectiveness is directly influenced by virtual team size. Pinjani and Palvia [32] explored the mediating effects of trust and knowledge sharing in mitigating the negative effects of diversity in the team and found that it is essential in such an environment to motivate mutual trust and knowledge sharing. The task interdependence and collaborative capabilities of technology have significant impact on the functioning of team processes [38].

The results of this scientist's research showed the importance of dynamic factor in the rapidly changing environment, implementing personnel management objectives in the organization. These scientists offered a mean of integrated management, which allows harmonizing different management methods and approaches as well as methodologically grounded techniques for the realization of corporate strategic management models; they stressed the importance of improving corporate management systems, together with personnel management systems, strengthening integral relations between strategic, tactical and operative tasks in the management functions' implementation process and facilitating relations between those functions [9], [10]. Tools offered by different scientists create opportunities to form flexible corporate management systems together with personnel management systems characterized by high efficiency [24].

\section{Empirical Research}

It is necessary to find out what factors have influence on the system of personnel management of virtual and traditional organization, and what essential differences between different forms of organizations are in order to attain the results of research. Major purpose of the research is to explore and compare factors forming personnel management system in virtual and traditional organizations, and determine main factors influencing effectiveness of personnel management of virtual organization. To achieve such aim empiric research has been performed. Since relevant researches have not been performed for virtually working employees and necessary material on this topic has not been saved, initial data was collected for the research. In contrary, big amount of researches related with personnel management problems were performed with personnel who work in traditional companies, therefore, there is a possibility to compare already founded factors forming the effective personnel management system of traditional organization with new collected research data of virtual organizations [25], [39].

Research methodology is as follows. The quantitative survey was conducted in Lithuania, period of research 2014 March-May. For the research selected questionnaire survey method. The choice of method is based on the fact that, there could be the difference among the elements building the personnel management system of traditional and virtual organizations. Questioning the representatives of both types of organizations it is possible to compare the factors forming the personal management system, and to identify the elements of personnel management system, that are important building the personnel management system of virtual organization. Total are surveyed more than 100 organizations. For the research were selected two groups of organizations: business organizations, which according the criteria of Duoba and Savanevičienè [8] are identified as 
virtual organizations and second group - the traditional organizations.

The survey sample - for 55 organizations, that are members of association "INFOBALT" and meets the criteria of virtual organizations [8] by the e-mail was delivered the questionnaire. INFOBALT association is a locally and internationally recognized representative of Lithuanian ICT industry. The association, founded in 1994 has today more than 140 members, including national and global businesses, universities, colleges and research institutions involved in ICT education, employing more than 10,000 experienced ICT professionals, teachers and researchers. Companies, selected for our research had chosen one person who represent the company and is working in the virtual workplace, and who completed the questionnaire. Calculating the reliability of the data by Paniotto formula [42] showed that a total of 48 respondents should be interviewed from 55 organizations, at 5 percent relevance. In total, there were received 48 questionnaires. In this case the data of research are representative with 5 percent relevance. The control group was selected from 67 traditional businesses organizations and a total of 53 questionnaires were received.

The study was based on probability sampling method. For interviewing companies that fulfil the criteria of virtual organization where was the probabilistic selection method used, because the chances of the test element to be the sample was known. Profiles questionnaire was compiled using an online survey site www.publika.It. The questions were formulated in accordance with the guidelines and requirements of methodological questions in the questionnaire form [15], [41], [34], [42]. Questionnaires reference was sent to the personnel of virtual and traditional organizations. This form and method was chosen for several reasons. This profile is convenient for respondents to fill in and the form for the researcher is returned automatically, in addition saving the time to collect the questionnaire. Also, this method does not require large financial investments, and the results are easily imported into the selected computer processing program and can be dealt with a variety of selected sections.

On the base of analyses of the scientific literature was prepared structured questionnaire and formulated questions for the traditional and virtual organizations in order to investigate the important elements of personnel management of virtual organization. As a methodological basis for the questionnaire was used: 1) criteria of identification of virtual organizations [8]; 2) personnel motivation theoretical aspects [32], [5]; 3) theoretical aspects of recruitment, selection and employment of virtual organization personnel [45]; 4) effectiveness of personnel management [44] and others. All the questions in the questionnaire was formulated specifically to get certain results and divided into different groups: group 1, questions that intended to determine specific of personnel selection; group 2, formation of personnel management policy; group 3, motivation of personnel; group 4 , issues of informal communication and it's affect to personnel management; group 5, questions that intended to clarify the priorities of the individual employee and specifics of teamwork; group 6, questions designed to identify the respondents' age, gender or other characteristics. To avoid monotony on survey were selected different types of questions. For some of them needed to be short and succinct answers, allowing to deny or approve certain statements, answers other questions require more attention and concentration. The results or research were used for the formation the personnel management system of virtual organization.

\section{Personnel Management System of Virtual Organization}

As analytical object of personnel management problems, there is chosen a virtual organization, which appeared under the influence of information technologies development and globalization. There are submitted definitions of virtual organization as well as its description in the scientific literature, outlined its characteristics and features, affecting implementation of personnel management tasks.

On the grounds of accomplished scientific literature analysis and summarizing virtual organization's descriptions provided by various authors, there is revised and specified the definition of virtual organization, according to which, virtual organization is the form of collaboration joining work resources from different geographical places in order to implement common goals and which personnel work according to its competence. Presenting good or service to a third party it identifies 
itself as a single organization. Due to absence of physical contact between organization members, they inter-communicate and share resources for the implementation of the common goals using information technologies.

After analysing characteristics assigned to the virtual organization, there is stated that virtual organization has all features of traditional organization but due to the absence of physical contact between organization members, new managerial problems emerge, firstly, problems of personnel management. The question is how to successfully join personnel for implementation of set goals under new conditions and motivate employees to perform their tasks in time. Personnel management questions in the scientific literature generally are analysed having assumption that employee works in the same premises or he/she is easily reachable by supervising personnel.

Personnel management problems in virtual business organizations and priorities of their solution. According to an evolution nature point, problems of virtual organizations, which manage personnel by network, are divided into political, economic, social, technological and legal; by aspect of expression degree, problems are divided into global, international, regional on an international scale, national and regional on the state scale.

The underlying attention should be paid to: 1) identification of personnel management problems in the environment affected by changes of information technologies; 2) personnel management by information technologies, also in virtual organizations; 3) joining intellectual and geographically dispersed work resources by information technologies and using them in the solution of regional and national problems, together successfully taking business opportunities that emerge under globalization and acquiring competitive advantage.

After accomplishment of systematic analysis and empirical research, there is created personnel management model of virtual organization (see Fig. 1). Each element of model is explained in ongoing text.

\section{Fig. 1: Model of personnel management of virtual organization}

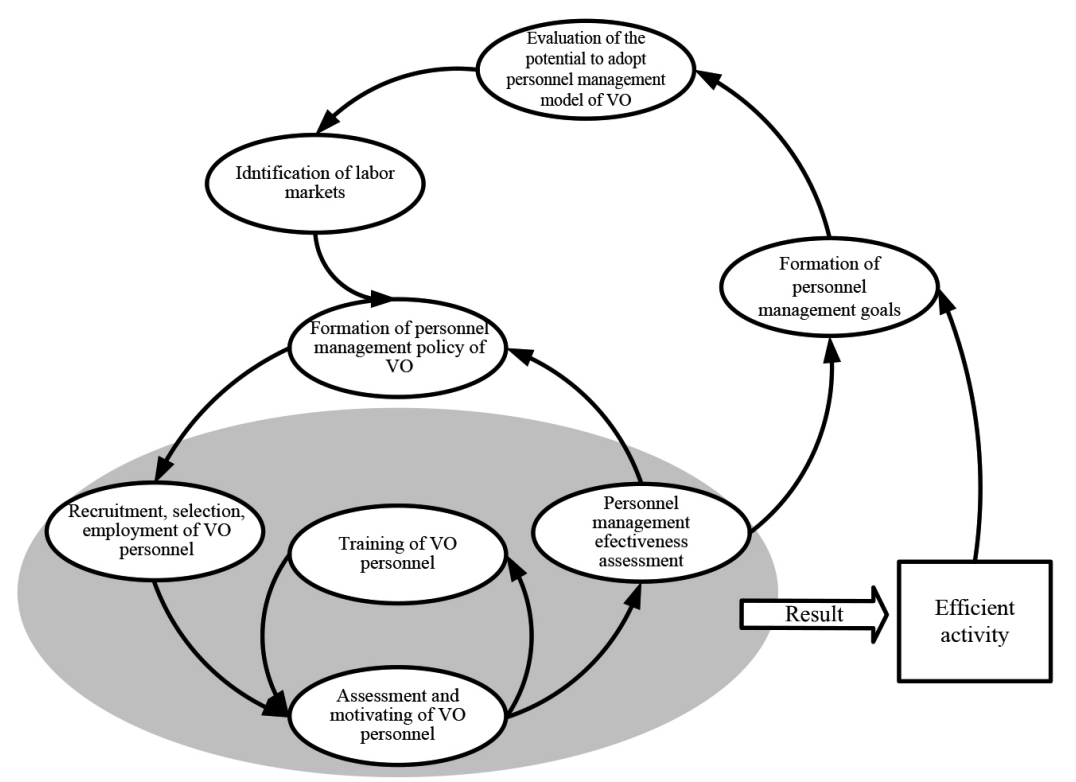


Formation of personnel management goals and evaluation of organization's potential to implement model of personnel management of virtual organization. For evaluation of organization's technical potential to manage personnel by network, it is proposed to use reasons and outcomes diagram, which creating procedure is as follows:

1. Preparative stage. There is selected a desirable result, which attainment's reasons are to be analysed. In studied case, it is the effectiveness of personnel management tasks implementation, using information technologies available in the company.

2. Data gathering and processing stage. There are proposed the possible technical reasons for personnel management tasks implementation problems. Technical reasons, that affect personnel management, can be described by the following function:

$$
y=f\left(x_{1}, x_{2}, \ldots . x_{n}\right),
$$

here $y$-personnel management tasks implementation effectiveness; $x_{n}$-technical reasons having impact on personnel management tasks solving.

As personnel management by network tasks implementation is strongly influenced by information technologies available in organization, possibilities to manage personnel by network in existing organizations are proposed being analysed according to the following criteria:

a) Investments into modern technologies which help solving personnel management problems $\left(x_{1}\right)$, which are measured by expert method in percentage expression from company's profit portion;

b) Information technologies usage level in organization $\left(x_{2}\right)$, which is determined by expert method, comparing information technologies available in the market and applied in organization for personnel management problems solving;

c) Information technologies usage level among organization's leaders, who are able to manage personnel by network $\left(x_{3}\right)$; the level is determined by expert method, comparing information technologies, which are installed at work by managers and which are potentially applicable there;

d) Acceptability of modern technical means among leaders $\left(x_{4}\right)$, which is measured by leaders' ability to install the needed information technologies in a certain time period;

e) Acceptability of modern technical means among personnel $\left(x_{5}\right)$, which is measured by personnel's ability to install the needed information technologies in a certain time period;

f) Priorities of communication means in organization $\left(x_{6}\right)$, which affect the selection of information technologies for personnel management.

The identification of potential labour markets. For labour markets analyses, it is offered to use adapted Zavadskas et al. [46] (electronic business and Internet decision support systems, which apply the method of multi-criteria analysis. In determining criteria values, it should be considered the positive and negative characteristics of the selective labour markets, their potential, and intercompatibility. Using interviews, questionnaires, or applying expert methods, determine the amount, values and significances of qualitative criteria. The assessment of labour markets is accomplished in the following order: there are chosen characterizing labour markets criteria $x_{1}-x_{m}$, which are described by Ž-conceptual information, expressible in numbers, formulas, and text; to every criterion there are assigned $d$-expert proposed measurement units, best describing chosen criteria; also, there are assigned q-expert proposed significances. Criteria proposed by author that describe labour markets: price of labour force; communication costs; unemployment rate; consumer expenditure level; technological environment; social cultural environment; influence of different time zones; political environment; legal environment; economic environment; potential labour market changes; labour market compatibility with other markets; other criteria, according to personnel management goals. There are chosen potential labour markets $D_{1}-D_{n}$, and using multi-criteria analysis they are being assessed, also, there are determined labour markets' selection priorities from $P_{1}$ to $P_{n}$.

Formation of personnel management policy. It is proposed to accomplish the formation of personnel management policy in the organization, according to organizational goals, in the following stages: 1) determination 
of personnel management principles: structure, systems, style; 2 ) determination of work nature principles; 3) determination of personnel motivational factors, creation of importance feeling; 4) determination of size for the most productive intellectual activity team, education and experience coordination; 5) formation of separate teams, i.e. organizational units, for performing different tasks, determining professional requirements for different members. Individual work or work in teams has to stimulate their members to improve knowledge and seize market opportunities. There should be determined the diversification of team members' knowledge as well as opportunities of functional cooperation; 6) formulation of tasks for different teams. Also, there is intended the work of different members in several virtual teams at the same time; 7 ) the principles and requirements for virtual learning and qualification raise are determined.

Recruitment, selection and employment of virtual organization personnel. Personnel selection is carried out in the following sequence: in the first stage electronic applications are accepted; in the second stage the initial selection is performed, according to recommendations of potential employees; further, tasks for candidates are created, determining evaluation criteria; according to set criteria, performed work is being assessed and summing up results, the decision, concerning personnel hiring, is made. Different methods of personal selection could be used, including self-assessment tests, online interviews, fuzzy method of staff selection, and others.

Assessment and motivation of personnel of virtual organization. Assessment and motivation of personnel in virtual organization is accomplished in the following order (see Fig. 2).

1. First of all, the centre (network agent), which performs personnel management functions, determines the scheduled personnel management tasks' status, which comprises the set of planned personnel management tasks

$$
\pi_{i}=\left\{\pi_{i}^{1}, \pi_{i}^{2}, \ldots, \pi_{i}^{n}\right\} .
$$

This set is conveyed to organization's personnel, i.e. to each $i$-th element.

2. Employees perform the activity $y_{i}^{j}$, which is expressed as of factual status accomplished tasks' set

\section{Fig. 2: Model of personnel assessment and motivation}

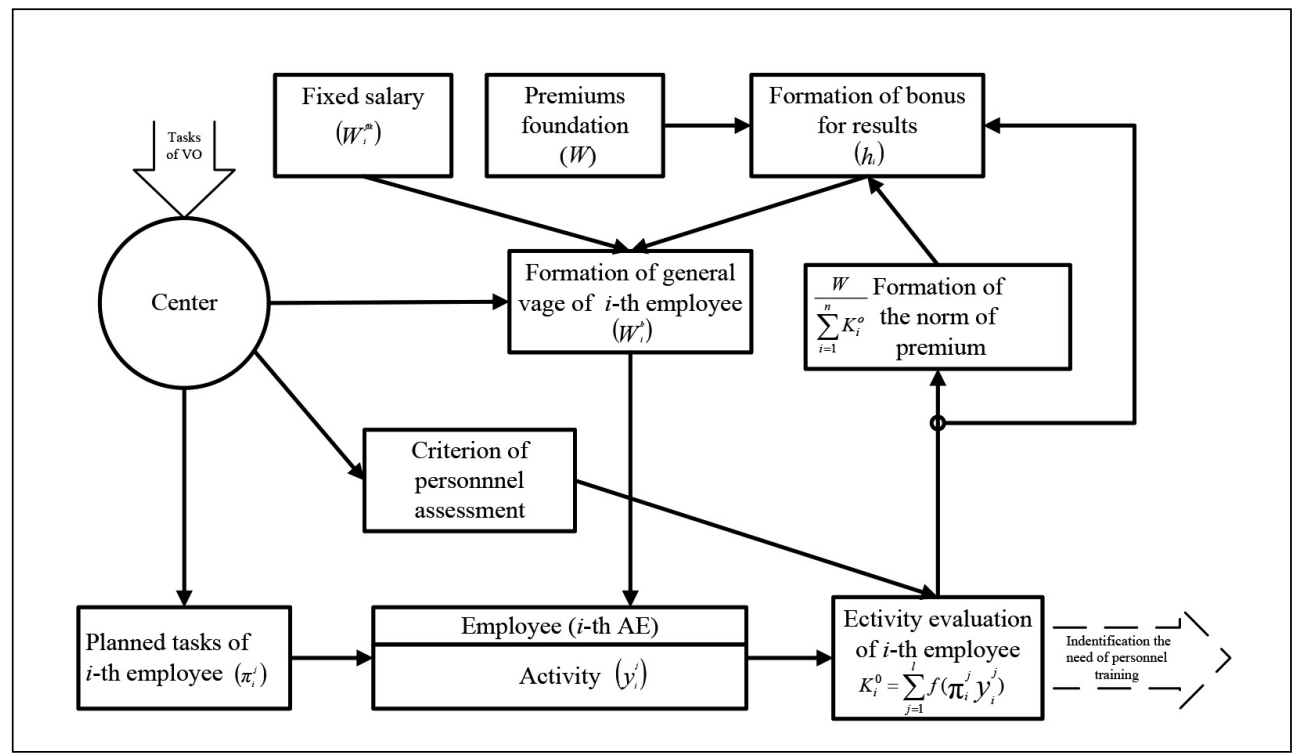




$$
y_{i}=\left\{y_{i}^{1}, y_{i}^{2}, \ldots, y_{i}^{n}\right\}
$$

3. Employees' activity is assessed according to the determined assessment criteria, which are set by selecting the functions of criteria determination, according to the specifics of personnel management tasks implementation. As employees' activity's evaluation indicators, there are selected corresponding sets

$$
K_{i}=\left\{K_{i}^{1}, K_{i}^{2}, \ldots, K_{i}^{n}\right\},
$$

which are set by selecting the functions of indicator determination (see Fig. 2):

a) Monotonically growing straight line; its characteristic is that coefficient, evaluating employee's (active element's) results, always is $K>0 ; K=1$ when $\mathrm{AE}$ results $y_{i}^{j}=\pi_{i}^{j}$, i.e. when scheduled personnel management goals are implemented. The mathematical expression of such function can be

$$
K_{i}^{j}\left(\pi_{i}^{j}, y_{i}^{j}\right)=\operatorname{tg} \alpha \cdot y_{i}^{j},
$$

b) Curve of parabola type, when in the initial stage the value of coefficient $K$, according to the results, grows not much. Personnel is stimulated to implement the tasks, which are close to planned ones, or to exceed them, its mathematical expression can be, e.g.:

$$
K_{i}^{j}\left(\pi_{i}^{j}, y_{i}^{j}\right)=y_{i}^{j^{n}},
$$

here $n$ degree chosen, according to the set goals.

c) Stair function, when the value of coefficient $K$ changes, according to $A E$ activity results in different intervals. Its mathematical expression could be, e.g.:

$$
K_{i}^{j}\left(\pi_{i}^{j}, y_{i}^{j}\right)=\left\{\begin{array}{l}
0, \text { if } \pi_{i}^{j}>a y_{i}^{j} \\
\frac{1}{n}, y_{i}^{j} \in[a ; b) \\
\frac{2}{n}, y_{i}^{j} \in\left[b ; \pi_{i}^{j}\right) \\
1, \text { if } \pi_{i}^{j} \leq y_{i}^{j}
\end{array},\right.
$$

where $a, b$-defined intervals; $n$-amount of intervals; figures 1,2-numbers of intervals.

d) Straight line function,

$$
K_{i}^{j}\left(\pi_{i}^{j}, y_{i}^{j}\right)=\left\{\begin{array}{l}
0, \text { if } \pi_{i}^{j}>y_{i}^{j} \\
1, \text { if } \pi_{i}^{j} \leq y_{i}^{j}
\end{array},\right.
$$

is used for minimizing difference between plan and employee results $y_{i}^{j}-\pi_{i}^{j} \rightarrow \min$.

4. For each criterion $\left(K_{i}^{j}\right)$, according to its importance, there is assigned a grade $\left(r_{i}^{j}\right)$, for each grade there can be determined a separate leverage indicator $\left(a_{i}^{j}\right)$.

5. After evaluating the values of all criteria, it is finally estimated, how personnel management tasks are implemented, aggregating indicators to $K_{i}^{\circ}$ - activity evaluation indicator,

$$
K_{i}^{o}=\xi\left(K_{i}^{1}, K_{i}^{2}, \ldots, K_{i}^{n}\right) .
$$

Indicators aggregating procedures are selected and coordinated, evaluating the importance of personnel management tasks. Using additive

$$
K_{i}^{o}=\sum_{j=1}^{l} K_{i}^{j}
$$

(summing-up indicators) and multiplicative

$$
K_{i}^{o}=\prod_{j=1}^{l} K_{i}^{j}
$$

(multiplying indicators) procedures, it is required to evaluate their effect to the final estimation result.

6. According to the activity evaluation indicator $K_{i}^{\circ}$, for $i$-th employee (AE) it is determined the size of material incentive $\left(h_{\mathrm{i}}\right)$, which employee, in accordance with achieved results, gets as a bonus from premium foundation intended for implementation of personnel management goals:

$$
h_{i}=f_{i}\left(\pi_{i}, y_{i}\right)=W_{i}^{f i k}{ }_{+} K_{i}^{o}\left(\pi_{i}^{j}, y_{i}^{j}\right) \frac{W_{c}}{\sum K_{i}^{0}\left(\pi_{i}^{j}, y_{i}^{j}\right)},
$$

$W_{c}$-foundation of employees (active elements) monetary incentives; $K_{i}^{\circ}$-personnel activity evaluation indicator; $W_{i}^{i \text { fik }}-i$-th $\mathrm{AE}$ 's (employee's) fixed salary.

7. For personnel it is paid the total wage, which is the sum of fixed salary and bonus for the results.

8. After evaluating achieved personnel results, new personnel management tasks as well as their implementation norms are created.

\section{Personnel management effectiveness} assessment. Effectiveness should be estimated in the following sequence: 1 ) selection of assessment criteria; criteria are selected, according to set personnel management goals; 
2) expert assessment of personnel management goals' implementation in accordance with each criterion; 3) determination of general total effectiveness indicator, which evaluates the general condition of personnel management goals' implementation in comparison with set goals; 4) formulation of propositions for personnel management improvement.

\section{Conclusions}

It can be stated that lack of attention for ICT management problems in virtual organizations in scientific studies, which are dedicated to personnel management problems is observed. Personnel management questions generally are analysed having assumption that employee works in the same premises or is easily reachable by supervising personnel.

Personnel management issues concerning virtual organization are analysed fragmentally, therefore, personnel management theoretical models and their application practice do not meet the latter-day market requirements, posed by the outspread of information technologies.

It is proposed personnel management model of virtual organization, which consists of few important parts:

The evaluation of the organizational potential to manage personnel by network. Analysed questions: organizational preparation to apply forms of virtual work, evaluation of possibilities to manage personnel by network.

Potential labour markets identification and personnel management policy formation. In this case, the following problems are to be analysed: evaluation of labour force potential prevailing in different regions, evaluation of labour force qualification, price, and other aspects, the search for personnel that are able to work by network and implement organizational goals, data base creation, formulation of personnel management policy.

Formation of virtual organization personnel. Problems concerned: technological principles of personnel recruitment, setting communication principles, establishing communication standards for common activity and determining personnel relationships within organization, evaluation of personnel needs and expectations, their consistency with organizational goals.

In organizing business activity under conditions of globalization and adapting personnel management by network model, the following priorities should be considered:
Virtual organizations formation priorities, which comprise personnel selection of virtual organization, determination of work nature principles, determination of personnel motivational factors, determination of size for the most productive intellectual activity team, problems of education and experience coordination, and others. Technological principles comprising communication, administration, project management, usage of supply chain systems, creation of electronic collaboration structure, forethought of collaboration content, usage of collaboration possibilities determined by a communication means.

Communication priorities that encompass protocol requirements of electronic nets, their definition and coordination, promotion of frequent interaction by network, determining the decision making processes, uncertainty assessment, the usage of informal signs interacting by information technologies and telecommunication means.

Relationships within an organization that include formulation of a personnel values' set, stimulation of maintaining personal contacts with other members of organization, attention to work relations management, others.

Motivation of virtual organizational members comprising the determination of motivational factors, personnel value perception, determination of confidence degree, admission and expression of individual feelings.

This implementation of priorities should be foreseen by formed virtual organizations' goals and strategies, also, personnel management process. Management by network has to be developed using systematic approach, emphasizing priorities in personnel management activity, taking into consideration defined organizational tasks and possibilities to coordinate them with personnel goals, together organizational activity has to be distinguished by flexibility and adaptability, according to market requirements.

\section{References}

[1] AGÜERO, J., et al. Towards the development of agent-based organizations through MDD. International Journal on Artificial Intelligence Tools. 2013, Vol. 22, Iss. 2, pp. 1-35. ISSN 02182130. DOI: 10.1142/S0218213013500024.

[2] ANDREJOVSKÁ, A., BÁNOCIOVÁ, A. Payment discipline in business environment. 
Procedia Economics and Finance. 2014, Vol. 15, pp. 1217-1224. ISSN 2212-5671. DOI: 10.1016/s2212-5671(14)00581-4.

[3] BEKKERS, V.E. E-Government and the Emergence of Virtual Organizations in the Public Sector. Information Polity. 2003, Vol. 8, Iss. 3/4, pp. 89-102. ISSN 1570-1255.

[4] BIGGS, D., SWAILES, S. Relations Commitment and Satisfaction inAgency Workers and Permanent Workers. Employee Relations. 2006, Vol. 28, Iss. 2, pp. 130-143. ISSN 01425455. DOI: 10.1108/01425450610639365.

[5] BRAHM, T., KUNZE, F. The role of trust climate in virtual teams. Journal of Managerial Psychology. 2012, Vol. 27, Iss. 6, pp. 595-614. ISSN 0268-3946. DOI: $10.1108 / 02683941211252446$.

[6] COHEN, A. Commitment Before and After. An Evaluation and Reconceptualization of Organizational Commitment. Human Resource Management Review. 2007, Vol. 17, Iss. 3, pp. 336-339. ISSN 1053-4822. DOI: 10.1016/j. hrmr.2007.05.001.

[7] DUBINAS, V. Darbuotojų ir klientų lojalumo reikšmé strateginiame organizacijos valdyme, Ekonomika ir vadyba: aktualijos ir perspektyvos. 2010, Vol. 17, Iss. 1, pp. 43-50. ISSN 1648-9098. [8] DUOBA, K., SAVANEVIČIENÉ, A. Organizacijų virtualumo raiška Lietuvoje. Ekonomika ir vadyba: aktualijos ir perspektyvos. 2010, Vol. 15, pp. 465-470. ISSN 1648-9098.

[9] GAVUROVÁ, B. Source Identification of Potential Malfunction of Balanced Scorecard System and Its Influence on System Function. E+M Ekonomie a Management. 2012, Vol. 15, Iss. 3, pp. 76-90. ISSN 1212-3609.

[10] GAVUROVÁ, B., ŠOLTÉS, M., BALLONI, A.J. The Economic Importance of Using of ICT in the Health System. Ekonomický časopis/ Journal of Economics. 2014, Vol. 62, Iss. 1, pp. 83-104. ISSN 0013-3035.

[11] GINEVIČIUS, R., et al. XXI amžiaus iššūkiai: organizaciju ir visuomenès pokyčiai. 1st ed. Vilnius: Technika, 2006. 548 p. ISBN 9955-28-057-3.

[12] GRAF, T. The future of OD: Developing an effective virtual organization for the OD network. OD Practitioner. 2009, Vol. 41, Iss. 3, pp. 30-36. ISSN 0032-6518.

[13] GRAŽULIS, V. Darbuotojų socializacija Lietuvoje: dabartinè situacija ir tobulinimo perspektyvos. Ekonomika ir vadyba: aktualijos ir perspektyvos. 2012, Vol. 27, Iss. 3, pp. 145155. ISSN 1648-9098.
[14] GRAŽULIS, V., MARKUCKIENĖ, E. Darbuotojų motyvacijos ir lojalumo stiprinimas plètojant kompetencijas. Ekonomika ir vadyba: aktualijos ir perspektyvos. 2013, Vol. 31, Iss. 3, pp. 142-151. ISSN 1648-9098.

[15] KARDELIS, K. Moksliniu tyrimy metodologija ir metodai. 1st ed. Kaunas: Judex, 2002. ISBN 9986-948-65-7.

[16] LEE, M.R. Leading Virtual Project Teams: Adapting Leadership Theories and Communications Techniques to 21st Century Organizations. 1st ed. Boca Raton: CRC Press, 2013. 217 p. ISBN 978-1-466-57688-9.

[17] LI, C., LI, L. Hierarchical control policy for dynamic resource management in grid virtual organization. The Journal of Supercomputing. 2009, Vol. 49, Iss. 2, pp. 190-218. ISSN 09208542. DOI: $10.1007 / \mathrm{s} 11227-008-0231-z$.

[18] LIN, C-P., et al. Assessing Online Learning Ability from a Social Exchange Perspective: A Survey of Virtual Teams within Business Organizations. International Journal of Human-Computer Interaction. 2010, Vol. 26, Iss. 9, pp. 849-867. ISSN 1044-7318. DOI: 10.1080/10447318.2010.496336.

[19] LIN, C., STANDING, C., LIU, C. A model to develop effective virtual teams. Decision Support Systems. 2008, Vol. 45, Iss. 4, pp. 1031-1045. ISSN 0167-9236. DOI: 10.1016/j.dss.2008.04.002. [20] MAGNUSSON, P., SCHUSTER, A., TARAS, V. A Process-Based Explanation of the Psychic Distance Paradox: Evidence from Global Virtual Teams. Management international review. 2014, Vol. 54, Iss. 3, pp. 283-306. ISSN 0938-8249.

[21] MAZILAUSKAITE், R., LEGKAUSKAS, V. Psichosocialiniu veiksnių j̇takos darbuotojų lojalumui tyrimas dirbančiujų Lietuvoje pavyzdžiu. Organizaciju Vadyba: Sisteminiai Tyrimai. 2013, Vol. 65, pp. 45-61. ISSN 1392-1142.

[22] MELNIKAS, B., et al. Intelektinis verslas. 1st ed. Vilnius: Technika, 2014. 456 p. ISBN 978-609-457-635-5.

[23] MINAS, R.K., et al. Putting on the Thinking Cap: Using NeurolS to Understand Information Processing Biases in Virtual Teams. Journal of Management Information Systems. 2014, Vol. 30 , Iss. 4, pp. 49-82. ISSN 0742-1222. DOI: 10.2753/MIS0742-1222300403.

[24] MOHELSKÁ, H., et al. The role of marketing in multinational subsidiaries: standardization versus localization. $E+M$ Ekonomie a Management. 2013, Vol. 16, Iss. 1, pp. 138-148. ISSN 1212-3609. 
[25] MOHELSKÁ, H., SOKOLOVÁ, M. Effectiveness of using e-learning for business disciplines: the case of introductory management course. E+M Ekonomie a Management. 2014, Vol. 17, Iss. 1, pp. 82-92. ISSN 1212-3609. DOI: 10.15240/tul/001/2014-1-007.

[26] MURA, L. Performance of Human Resource Management in an Internationally Operating Company. Serbian Journal of Management. 2012, Vol. 7, Iss. 1, pp. 115-129. ISSN 1452-4864.

[27] OGBA, I.E. Commitment in the Workplace. The Impact of Income and Age on Employee Commitment in Nigerian Banking Sector. Management Research News. 2008, Vol. 31, Iss. 11, pp. 867-878. ISSN 0140-9174. DOI: 10.1108/01409170810913051.

[28] PĂCURARU, R-O. Virtual Organizations. Journal of Academic Research in Economics. 2011, Vol. 3, Iss. 3, pp. 347-354. ISSN 20660855.

[29] PANGIL, F., CHAN, J.M. The mediating effect of knowledge sharing on the relationship between trust and virtual team effectiveness. Journal of Knowledge Management. 2014, Vol. 18, Iss. 1, pp. 92-106. ISSN 1367-3270. DOI: 10.1108/JKM-09-2013-0341.

[30] PARISH, J.T., CADWALLADER, S., BUSCH, P. Want to, Need to, Ought to: Employee Commitment to Organizational Change. Journal of Organizational Change Management. 2008, Vol. 21, Iss. 1, pp. 32-52. ISSN 0953-4814. DOI: 10.1108/09534810810847020.

[31] PICARD, W. Semantic modelling of virtual organizations with service network schemata. New Generation Computing. 2012, Vol. 30, Iss. 2-3, pp. 99-121. ISSN 0288-3635. DOI: 10.1007/s00354-012-0201-0.

[32] PINJANI, P., PALVIA, P. Trust and knowledge sharing in diverse global virtual teams. Information \& Management. 2013, Vol. 50, Iss. 4, pp. 144-153. ISSN 0378-7206.

[33] RASHID, M.Z.A., SAMBASIVAN, M., JOHARI, J. The Influence of Corporate Culture and Organisational Commitment on Performance. Journal of Managerial Development. 2003, Vol. 22, Iss. 8, pp. 708728. ISSN 0262-1711.

[34] RAUDONIUS, S. Moksliniu tyrimy planavimas ir analizé. Kaunas: IDP Solutions, 2008. ISBN 978-9955-865-18-6.

[35] SÁNCHEZ-ANGUIX, V., VALERO, S., GARCIA-FORNES, A. A genetic approach for long term virtual organization distribution.
International Journal on Artificial Intelligence Tools. 2011, Vol. 20, Iss. 2., pp. 271295. ISSN 0218-2130. DOI: 10.1142/ S0218213011000152.

[36] SARKER, S., et al. The role of communication and trust in global virtual teams: a social network perspective. Journal of Management Information System. 2011, Vol. 28, Iss. 1, pp. 273-309. ISSN 0742-1222. DOI: 10.2753/MIS0742-1222280109.

[37] SINIČÁKOVÁ, M. Transmission of inflation and economic growth in the euro area in the respect to a single monetary rule. Journal of Applied Economic Sciences. 2013, Vol. 8, Iss. 4, pp. 499-509. ISSN 1843-6110.

[38] ŠOLTÉS, V., GAVUROVÁ, B. The functionality comparison of the health care systems by the analytical hierarchy process method. E+M Ekonomie a Management. 2014, Vol. 17, Iss. 3, pp. 100-117. ISSN 1212-3609. DOI: 10.15240/tul/001/2014-3-009.

[39] SZABO, K., ŠOLTÉS, M., HERMAN, E. Innovative Capacity and Performance of Transition Economies: Comparative Study at the Level of Enterprises. E+M Ekonomie a Management. 2013, Vol. 16, Iss. 1, pp. 52-68. ISSN 1212-3609.

[40] TAMOŠıŪNAITÉ, R. Organization virtual or networked? Social technologies. 2011, Vol. 1, Iss. 1, pp. 49-60. ISSN 2029-7564.

[41] TIDIKIS, R. Socialiniy moksly tyrimy metodologija. 1st ed. Vilnius: Lietuvos teisès universiteto Leidybos centras, 2003. ISBN 9955563265.

[42] VALACKIENÉ, A., MIKĖNE், S. Sociologinis tyrimas: metodologija ir atlikimo metodika. 1st ed. Kaunas: Technologija, 2008. ISBN 9789955254706.

[43] VERBURG, R.M., BOSCH-SIJTSEMA, P., VARTIAINEN, M. Getting it done: Critical success factors for project managers in virtual work settings. International Journal of Project Management. 2013, Vol. 31, Iss. 1, pp. 68-79. ISSN 0263-7863.

[44] WILSON, J., CRISP, C.B., MORTENSEN, $M$. Extending construal-level theory to distributed groups: understanding the effects of virtuality. Organization Science. 2012, Vol. 24, Iss. 2, pp. 629-644. ISSN 1047-7039.

[45] XIAO, Y.-C., JIN, Y-H. The hierarchical linear modelling of shared mental model on virtual team effectiveness. Kybernetes. 2010, Vol. 39, Iss. 8, pp. 1322-1329. ISSN 0368492X. DOI: 10.1108/03684921011063619. 


\section{Informační management}

[46] ZAVADSKAS, E.K., et al. Multi-Attribute Decision-Making Model by Applying Grey Numbers. Informatica. 2009, Vol. 20, Iss. 2, pp. 305-320. ISSN 0868-4952.

[47] ZOU, Y., et al. A layered Virtual Organization architecture for grid. The Journal of Supercomputing. 2010, Vol. 51, Iss. 3, pp. 333-351. ISSN 0920-8542. DOI: 10.1007/ s11227-010-0387-1.

assoc. prof. Juozas Merkevičius, Dr. Vilnius Gediminas Technical University Faculty of Business Management Department of Business Technologies juozas.merkevicius@vgtu.It assoc. prof. Vida Davidavičienè, Dr.

Vilnius Gediminas Technical University

Faculty of Business Management

Department of Business Technologies vida.davidaviciene@vgtu.It

assoc. prof. Jurgita Raudeliūnienè, Dr. Vilnius Gediminas Technical University Faculty of Business Management Department of Business Technologies jurgita.raudeliuniene@vgtu.It

assist. prof. Dr. Jan Buleca, Ing., DVM, PhD. Technical University of Košice Faculty of Economics Department of Finance jan.buleca@tuke.sk 


\section{VIRTUAL ORGANIZATION: SPECIFICS OF CREATION OF PERSONNEL MANAGEMENT SYSTEM}

\section{Juozas Merkevičius, Vida Davidavičienè, Jurgita Raudeliūnienè, Jan Buleca}

Development of new types of organizations such as a Virtual organization brought for society certain possibilities and opportunities which usually are named as advantages, but also they can be observed as challenges or even named as a problems within organization. Models and methods applied in personnel management should be adequate and meet requirements of markets and present newest scientific mind in order not to cause decrease of competitiveness, loss of potential markets, not to cause social problems, such as unemployment, migration, disproportion between regions, etc. Due to the following reasons, the perception of personnel improvement problems and their solutions stand not only for business development factor. These circumstances formed the topicality of the article subject. Virtual organizations formation priorities contains personnel selection of virtual organization, determination of work nature principles, determination of personnel motivational factors, determination of size for the most productive intellectual activity team, problems of education and experience coordination, others. In organizing business activities under current globalization trends and adapting personnel management by network model, implementation of these priorities should be foreseen by formed virtual organizations'goals and strategies, as well as personnel management process. Management by network has to be developed using systematic approach, emphasizing priorities in personnel management activity, taking into consideration defined organizational tasks and possibilities to coordinate them with personnel goals, together organizational activity has to be distinguished by flexibility and adaptability, according to market requirements. Goal of the research was to construct a model of personnel management of virtual organization that create possibilities to manage geographically dispersed personnel using information technologies. Methods of the research - there was applied systematic analysis that allowed disclosing personnel management specifics under the conditions of virtual organizations' development. In performing the research there were used methods of comparison, summarization and documentary analysis.

Key Words: Virtual organization, globalization, personnel management, information and communication technologies.

JEL Classification: M12, M15.

DOI: 10.15240/tul/001/2015-4-014 